\title{
STRATEGI MENGENALKAN AL-QURAN SEJAK PENDIDIKAN DASAR DI LEMBAGA PENDIDIKAN HIDAYATULLAH KUDUS JAWA TENGAH
}

\author{
Moh Rosyid \\ Institut Agama Islam Negeri (IAIN) Kudus Jawa Tengah \\ mrosyid72@yahoo.co.id
}

\begin{abstract}
Abstrak
Riset ini bertujuan untuk memahami kekhasan pembelajaran menanamkan cinta alQuran bagi siswa Sekolah Dasar Islam Terpadu Yayasan al-Aqsho Lembaga Pendidikan Hidayatullah di Kudus Jawa Tengah. Data diperoleh dengan literature dan observasi, analisis yang digunakan deskriptif kualitatif. Dimana penelitian kualitatif ini memudahkan proses penelitian untuk digambarkan lebih spesifik sesuai dengan tujuan penelitian. Hasil riset, model pembelajarannya inquiri, project, and problem based learning, dan discovery learning. Ketiganya memadukan tiga gaya belajar yakni penglihatan, pendengaran, dan gerak. Ekstrakulikulernya qiroah, kaligrafi, pramuka, panahan, pianika, paduan suara, rebana, beladiri, jurnalistik, dan seni mewarnai. Profil yang diobsesikan akidah yang lurus, berakhlak al-Quran, semangat beribadah dengan berjamaah sebagai bekal mewujudkan kecerdasan qolbu. Kredonya, membuka hati dengan pendidikan integral berbasis tauhid dan mewujudkan terciptanya generasi yang berakhlakul karimah, tertradisi membaca al-Quran di kelas, asrama, masjid, dan menghapalkannya. Hal ini didukung dengan pelaksanaan pendidikan karakter religius, jujur, disiplin, mandiri, tanggung jawab, suka membaca al-Quran dan menghapalnya menjadi budaya sekolah.
\end{abstract}

Kata Kunci: Hidayatullah, generasi quran, dan berakhlakul karimah

\begin{abstract}
This research aims at understanding especially learning student elementary school in SDIT under the auspices of Yayasan al-Aqsho Pesantren Hidayatullah Kudus. Data of this paper are gathered through literature, interview and observation which then analyzed in descriptive qualitative method. Where this qualitative research facilitates the research process to be described more specifically in accordance with the research objectives. Al-Aqsha Hidayatullah Foundation is unique for its role play learning inquiri, project, problem based learning, and discovery learning. The model's, to combined three models learning, visual, auditory, and kinetic. The ekstrakulikuler covers qiroah, kaligrafi, scout, archery, piano and choir, tambourine, pencak silat, jurnalistic, dan coloring art. Expected figure straight akidah, morality Quran, the spirit of worships, for intellectual and intelegents qolbu. Motto, heart open by integral education and tauhid basic. The hope, realy etic generation, get used to read al-Quran and memorize. This institution supported character education are religiousity, honest, discipline, responsible, love to read and memorize the Quran and make school culture.
\end{abstract}

Keywords: Hidayatullah, al-Quran generation, and morality. 


\section{PENDAHULUAN}

Rencana Program Jangka Menengah (RPJMN) 2020-2024 oleh Presiden Jokowi dan Wapres Ma'ruf Amin dengan 7 tujuh poin (1) menguatkan pertahanan perekonomian demi pertumbuhan yang kualitas, (2) pengembangan wilayah untuk pengurangan kesenjangan, (3) peningkatan SDM berkualitas dan berdaya saing, (4) revolusi mental dan membangun kebudayaan, (5) penguatan infrastruktur pendukung berkembangnya perekonomian dan pelayanan dasar, (6) pembangunan lingkungan hidup, peningkatan ketahanan bencana dan perubahan iklim, dan (7) penguatan stabilitas hukum, politik, pertahanan dan keamanan dan transformasi pelayanan publik. Poin ketiga, mewujudkan peningkatan SDM yang berkualitas dan berdaya saing bila pembangunan manusia Indonesia sejak usia dini. Maka pendidikan dasar harus diperhatikan pemerintah dan keterlibatan masyarakat dengan evaluasi program wajib belajar sembilan tahun.

Era teknologi informasi dengan mudahnya mengakses pemberitaan dari ragam sumber sebagai penanda bahwa orang mudah mendapatkan informasi, termasuk anak. Hanya saja, bila orangtua tidak mewaspadai, info yang hoax menjadi bumerang seperti pemanfaatan handphone untuk berselancar di dunia maya yang melebihi batas. Di sisi lain, anak harus dikenalkan ilmu dasar agar berjati diri. Menyikapi hal ini, lembaga pendidikan Hidayatullah di bawah naungan Yayasan al-Aqsha di Kudus Jawa Tengah berupaya mengenalkan dan menanamkan rasa cinta anak didiknya di jenjang sekolah dasar (SD) agar memanfaatkan waktu membaca al-Quran secara rutin. Kecintaan pada al-Quran sebagai prinsip dasar yang menjadi program unggulannya.

Naskah ini mengkaji kekhususan yang dikaji karena lazimnya sekolah dasar (SD) tidak memiliki program khusus cinta al-Quran. Polanya, kemasan kurikulumnya integratif, nama jenjang pendidikannya Sekolah Dasar Islam Terpadu (SDIT) Luqman al-Hakim, berobsesi mewujudkan siswa yang "berkarakter djitu" yakni berdisiplin, penuh kejujuran, islami, tekun, dan unggul. Naskah ini mennelaah di Kota Kudus Jawa Tengah (Lembaga Hidayatullah tersebar di ragam daerah) karena pertama, meluruskan adanya anggapan sebagian pihak publik karena ketidakpahamannya tetang lembaga ini muncul kecurigaan. Hal ini akibat hanya melihat pola manajerialnya dengan berpakaian 'islami' dalam pembelajaran di luar pembelajaran di kelas seperti bercelana 'khas', bergamis, bagi sang ustad (ada yang) berjenggot, dan bagi ustadzah berjilbab rapat, panggilan pada pendidiknya ustad/ustadzah, bukan guru. Kedua, siswa didik difasilitasi asrama sehingga kegiatan harian rutin dipantau oleh guru pamong. Ketiga, membaca al-Quran dijadikan tradisi. Keempat, kajian keislaman sebagai rutinitas. Walaupun demikian, lembaga ini menaati kurikulum nasional, hanya saja memiliki kekhasan, sebagaimana kajian naskah ini.

Lembaga ini dinamis sehingga para peneliti mengkajinya dengan ragam telaah. Pertama, Dianto, mendalami Lembaga Hidayatullah di Kota Tulungagung, Jawa Timur. 
Peran Lembaga Amil Zakat Nasional Baitul Maal Hidayatullah dalam berkinerja pijakannya pada empat poin, mewakafkan al-Quran, memberi beasiswa pendidikan bagi siswanya, santunan fakir dan miskin, membudidayakan lele dan kambing (Dianto, 2014). Kedua, Zein, Ponpes Hidayatullah di Yogyakarta didirikan atas dasar semangat berdakwah demi kualitas kehidupan muslim, kaderisasi da'i, pendirian panti asuhan, lembaga pendidikan nonformal seperti taman pendidikan al-Quran, dan pendidikan formal jenjang kelompok bermain, taman kanak-kanak/TK, hingga SMA, program berdakwah berupa majelis taklim, dakwah radio, pos dai, dan lembaga sosial seperti panti asuhan, search and rescue (SAR), dan Baitul Mal Hidayatullah (BMH) dengan dibentuk yayasan (Zein, 2018). Ketiga, Rukah, peran BMH dengan optimalisasi zakat dalam program Senyum Anak Indonesia yang memberikan beasiswa pada santri melalui wali santrinya yang mondok di Pondok Pesantren al-Burhan Hidayatullah di Desa Gedawang, Banyumanik, Kota Semarang.

Pemberian beasiswa disertakan kesepakatan bagi mustahiq (penerima) pasca menyelesaikan studi melakukan pengabdian selama satu tahun di lembaga Hidayatullah. Upaya yang dilakukan 'amil penghimpunan, pengelolaan, dan penentuan pihak penerima (mustahiq) dan pengawasan potensi mustahiq dan upaya inovasi pendayagunaan zakat. Dampak positifnya bagi mustahiq adalah mampu lulus atas fasilitas dari Baitul Maal Hidayatullah (Rukah, 2019). Para peneliti menelaah ragam aspek bidang finansial dan dinamikanya, sedangkan naskah ini mengkaji aspek ciri khas pengelolaan pendidikan dasar Hidayatullah di Kudus Jawa Tengah dalam menanamkan kecintaan pada al-Quran. Dengan demikian, naskah ini mendalami aspek yang baru maka perlu ditelaah.

Permasalahan penelitian ini bagaimana lembaga pendidikan dasar Hidayatullah di Kudus dalam upayanya mengenalkan anak didiknya mencintai al-Quran? Bagaimana model pendidikan karakter yang ditanamkan? Naskah ini ditulis bertujuan mengetahui dinamika lembaga Hidayatullah di Kota Kudus dalam upayanya mendidik peserta didiknya menjadi generasi pecinta al-Quran dan model pendidikan karakternya. Mencintai al-Quran merupakan sendi dasar mencintai Islam sehingga diharapkan lahir kader militan yang mencintai dan fasih membacanya. Upaya ini diharapkan mengilhami bagi lembaga lain dalam berupaya menanamkan pula pada anak didik mentradisikan membaca al-Quran dengan penanaman cinta. Hal yang harus dipahami pembaca, Lembaga Pendidikan Hidayatullah memiliki program integrasi dalam pembelajaran keislaman plus yaitu kaderisasi siswa menjadi calon pendakwah di wilayah Indonesia bagian Timur yang keislamannya perlu dioptimalkan. 


\section{METODE}

Artikel ini merupakan hasil riset penulis tahun 2021 data diperoleh dengan observasi dan kajian literatur. Observasi di lembaga pendidikan Hidayatullah Kudus, analisis datanya dengan pendekatan deskriptif kualitatif. Penelitian ini jenis penelitian kualitatif deskriptif yang mendeskripsikan hasil temuan penelitian dalam paparan data, bukan angka (kuantitatif). Data riset ini bersumber dari subyek riset yakni guru dan siswa di Lembaga Pendidikan Hidayatullah di Kudus. Tahapan penelitian ini (1) studi awal dengan mengkaji referensi dasar-dasar kependidikan, (2) survei awal untuk mendalami kondisi riil lembaga pendidikan Hidayatullah di bawah naungan Yayasan al-Aqsha Kudus, (3) survei lanjutan dan pengumpulan data dengan mengobservasi, literatur, dan dokumentasi, (4) menyusun sistematika penelitian untuk membahas obyek kajian pada bab pembahasan, dan (5) menyimpulankan, diakhiri dengan daftar pustaka.

\section{HASIL PENELITIAN DAN PEMBAHASAN}

\section{Dinamika Lembaga Hidayatullah}

Lembaga Hidayatullah awal pendiriannya sejak dideklarasikan oleh Abdullah Said bin Abdullah Kahar Syuaib. Abdullah Said atau Muhsin Kahar pada tahun 1952 s.d 1955 sekolah di Sekolah Rakyat (SR) hingga kelas 3 karena keluarganya berpindah ke Kota Makassar. Studinya dilanjutkan di Sekolah Rakyat kelas 4 hingga tahun 1958. Studi selanjutnya di Pendidikan Guru Agama Negeri (PGAN) 6 tahun di Kota Makassar, kuliah di Institut Agama Islam Negeri (IAIN) Alauddin Makassar hingga semester dua. Kegiatan sosial Said antara lain di Lembaga Pemuda Pelajar Islam (LPPI) tahun 1965 dan Pemuda Muhammadiyah di Malimongan Baru Makassar, ia menjabat sebagai Ketua Biro Dakwah dan Publikasi Pengurus Wilayah Sulawesi Selatan dan Tenggara pada periode 1966-1968. Selain itu di Lembaga Pemuda Pelajar Kesatuan Aksi Pemuda dan Pelajar Indonesia (KAPPI) Sulawesi Selatan dan Himpunan Pemuda Pelajar Mahasiswa Sinjai (HIPPMAS).

Selanjutnya Said mondok di Pondok Pesantren Gontor Ponorogo Jawa Timur dan di Pondok Pesantren Persis Bangil, Jawa Timur. Setelah selesai menuntut ilmu tersebut, ia berencana mendirikan pondok pesantren, tapi baru berusia 20 tahun sehingga keluarganya tidak mendukungnya. Pada tahun 1972 ia berpindah di Kota Balikpapan untuk mendirikan Pondok Pesantren Hidayatullah yang kini tumbuh di berbagai daerah di Nusantara. Pada tahun 2013 Hidayatullah memiliki 33 Dewan Pimpinan Wilayah (DPW) tingkat provinsi, 287 Dewan Pimpinan Daerah (DPD) tingkat kabupaten/kota, dan 70 Pimpinan Cabang (PC), Pimpinan Ranting (PR), dan Pimpinan Anak Ranting (PAR). Pengembangan lembaganya dengan didirikannya kampus yakni Sekolah Tinggi Ilmu Syariah (STISID) di Balikpapan, Sekolah Tinggi Ilmu Ekonomi Hidayatullah (STIEHid) di Depok, Jawa Barat, Sekolah Tinggi Agama Islam (STAI) Luqman Al-Hakim di Surabaya.

Selain itu mendirikan juga lembaga pendidikkan dan sosial yakni Pusat Pendidikan Anak Saleh (PAS) yang peserta didiknya yatim- piatu berasrama. Jenjang pendidikan 
formalnya dari Taman Kanak-Kanak (TK) dan Kelompok Belajar (KB), SD/MI, SMP/MTs, SMA/MA, SMK, dan 3 perguruan tinggi. Didirikan pula lembaga bidang dakwah yaitu Hidayatullah Training Center (Rosyid, 2020). Lembaga Hidayatullah pada Musyawarah Nasional pertama pada 9-13 Juli 2000 memutuskan menjadi ormas (organisasi sosial kemasyarakatan) dan gerakan dakwah Islam yang terbuka dengan pijakan pemurnian (purifikasi) ajaran Islam. Pilihan gerakannya bidang pemberdayaan sosial, dakwah, dan pendidikan. Untuk bidang pendidikan formal fokus pada tradisi membaca dan memahami al-Quran agar menjadi generasi cinta al-Quran, berorientasi modernis dan transformasi sosial untuk kemaslahaan warga muslim di Indonesia.

\section{Dinamika Hidayatullah di Kota Kudus Jawa Tengah}

Lembaga Hidayatullah eksis di Kota Kudus semenjak tahun 1992 diawali mengaji al-Quran model sorogan yakni santri membaca dan disimak oleh ustad/kiai. Pendakwah Hidayatullah berasal dari Surabaya, yakni Imam Syahid, Abdurrahman, dan Fatih mendapat tugas khusus dari Pimpinan Hidayatullah di Surabaya untuk mendakwahkan visi-misi Hidayatullah di Kudus. Ketiga mubaligh Hidayatullah tersebut datang di Kudus dengan bekal Majalah Hidayatullah untuk dipasarkan pada publik dan hasil penjualannya untuk akomodasi selama di Kudus. Tujuan Kota Kudus sebagai lokasi barunya atas inisiatif Pimpinan Hidayatullah di Surabaya dengan bekal alamat orang di Kudus yakni Sulkan Abdul Malik, notaris. Hanya saja sang notaris kurang merespon. Perjalanan dilanjutkan di Desa Tahunan Kota Jepara, tetangga Kudus, uuntuk bertemu dengan pihak yang dianggap memiliki visi yang sama. Akan tetapi, Imam pun kurang mendapat respon positif pula sehingga ke Kudus lagi untuk menemui Sonhaji di Desa Ploso, Kecamatan Jati. Upaya ini mendapat respon positif dengan diberi kesempatan bersinggah di rumahnya selama dua minggu. Posisi ini, Imam mencari informasi dan mendapat kabar ada pihak yang akan mewakafkan tanahnya (muwakif) untuk pengembangan Islam di Kudus. Imam menjumpai Abdul Malik (calon muwakif) tetapi belum menghasilkan sebagaimana rencana. Imam bersama dua temannya kembali lagi ke Kota Surabaya untuk memberi info upayanya di Kudus yang belum berhasil.

Kegagalan tahap awal di Kudus, Imam pada tahap kedua kembali ke Kudus berencana mengontrak rumah untuk sementara dengan biaya kontrak setahun Rp 500 ribu. Rencana ini ditolak Pimpinan Hidayatullah di Surabaya dan disarankan ke Kudus tanpa mengontrak. Imam melakukan strategi agar hidup di Kudus dengan biaya ekonomis menjadi santri mukim di Pondok Pesantren di Kauman Menara Kudus. Imam agar bertahan hidup, menjual Majalah Hidayatullah keliling antar-kampung harga pPer eksemplar Rp 1.500 dengan bersepeda ontel. Sepeda ini dana pembeliannya berasal dari donasi rekannya. Di tengah menjual majalah, ia sembari mencari informasi muwakif tanah untuk didirikan lembaga Hidayatullah di Kudus. Imam bertemu Widodo yang mendapat informasi dari Kurtubi bahwa Sumiyadi, adalah calon muwakif tanah. Imam bertemu Sumiyadi yang 
selanjutnya diberi kesempatan menempati rumahnya di belakang Masjid Al-Makruf (dekat Pasar Kliwon) Desa Rendeng, Kecamatan Kota. Imam menempati rumah tersebut selama dua tahun yang digunakan pula untuk tempat kajian al-Quran bagi warga yang berminat. Guru mengajinya lima mahasiswa Fakultas Ushuluddin IAIN Walisongo Semarang di Kudus (kini IAIN Kudus). hanya saja, forum mengaji tersebut, ada pihak yang kurang respek dan berkirim surat pada Imam agar dibentuk kepengurusan mengaji. Bila tidak dibentuk agar meninggalkan kampung tersebut. Imam menindaklanjuti permohonan tersebut dengan melakukan pertemuan dengan warga setempat dengan pihak calon kepengurusan pesantren.

Perjalanan panjang Imam, menimbulkan iba dari Sumiyadi (muwakif) akan mewakafkan rumah yang kini digunakan mengaji warga di Dukuh Grogol, Desa Bakalan Krapyak, Kecamatan Kaliwungu, meski pengajian di rumah tersebut tidak maksimal. Sejak tahun 1992 rumah digunakan Imam mengaji al-Quran. Pada perkembangannya, jumlah santri ada 30 berasal dari berbagai daerah. Setahun kemudian, Sumiyadi secara resmi mewakafkan rumah dan tanahnya untuk lembaga Hidayatullah hingga kini. Perkembangan selanjutnya, lembaga Hidayatullah menerima wakaf berupa tanah di pinggir jalan, jalur Kudus-Jepara di Desa Kedungdowo, Kecamatan Kaliwungu, Kudus dari H. Mas'an. Kini, tanah wakaf tersebut diperuntukkan sebagai Kantor DPD Hidayatullah Kudus, asrama, sekolahan, masjid, dan boarding school hanya siswa putra dan guru pamong beserta keluarganya (Rosyid, 2019).

Lembaga Hidayatullah secara nasional merujuk Piagam Gunung Tembak (Piagam Hidayatullah) (1) membangun peradaban Islam sebagai jihad tiap muslim, (2) pusat peradabannya adalah masjid, tiap kader wajib menjadikan masjid sebagai pusat ibadah, pengembangan keilmuan dan karakteristik kepemimpinan, (3) tiap kader wajib salat wajib di masjid, salat nawafil, terutama qiyamul lail, membaca al-Quran, dan beribadah sesuai ajaran Islam, (4) tiap kader merupakan generasi Rabbani yakni diwajibkan menghidupkan majlis ilmu, membangun tradisi keilmuan dan berdakwah. Dengan demikian, diwajibkan berhalaqoh (berdiskusi) sebagai media transformasi keilmuan, mentransformasikan karakter dan berkarakter sosial, (5) peduli, gemar menolong dan berkurban, tawadluk, militan, qona'ah, dan mengutamakan kehidupan akhirat, dan (6) tiap pemimpin dan kader wajib menjadi tauladan bagi umat dengan solidaritas jamaah dan persaudaraan/ukhuwah. Piagam tersebut ditandatangani oleh Abdurrahman Muhamad, Pemimpin Umum Hidayatullah, Hamim Thohari, Ketua Dewan Syuro, Abdullah Ihsan, Ketua Dewan Majelis Pertimbangan Pusat, dan Abdul Manan Ketua Umum mengesahkan Piagam pada 24 Juni 2013.

Kinerjanya sesuai Piagam Gunung Tembak (Piagam Hidayatullah) (1) membangun peradaban Islam sebagai jihad, (2) pusat peradabannya masjid, tiap kader wajib menjadikannya pusat ibadah, pengembangan keilmuan dan karakteristik kepemimpinan, (3) tiap kader wajib salat wajib, salat nawafil terutama qiyamul lail, membaca al-Quran, 
dan beribadah lainnya, (4) tiap kader merupakan generasi Rabbani yakni diwajibkan menghidupkan majlis ilmu, membangun tradisi keilmuan dan berdakwah dan berhalaqoh (berdiskusi) sebagai media transformasi keilmuan, karakter diri dan sosial, (5) peduli, gemar menolong dan berkurban, tawadluk, militan, qona'ah, dan mengutamakan kehidupan akhirat, dan (6) tiap pemimpin dan kader diwajibkan menjadi tauladan bagi umat dengan solidaritas jamaah dan persaudaraan/ukhuwah.

Perkembangannya kini, Lembaga pendidikan formal Hidayatullah di Kudus meliputi Kelompok Bermain (KB), Taman Kanak-Kanak Ya Bunayya sejak tahun 2002, SDIT Luqman Al-Hakim sejak 2001, SMP Islam Integratif Putri sejak 2004, SMP Islam Integratif Putra sejak 2010, SMK Hidayatullah Putra bidang jaringan komputer sejak 2015. Untuk KB, TK, SD, dan SMP putri di Kampung Grogol Loji, Desa Bakalan Krapyak, sedangkan jenjang SMP dan SMK untuk putra saja di Jl.Raya Kudus-Jepara KM.5 Desa Kedungdowo, Kecamatan Kaliwungu. Tahap selanjutnya, Lembaga Hidayatullah mendirikan lembaga keuangan syariah (Baitul Mal Wat-Tamwil/BMT Amanah (Syariah Micro Finances) melayani simpan-pinjam dana dan melayani pembayaran air minum (PAM), listrik (PLN), dan pembayaran zakat. Lembaga ini berkantor di Dukuh Grogol, Desa Bakalan Krapyak. Dikembangkan pula pelayanan servis komputer, Inova service, dan jual beli printer komputer di Desa/Kecamatan Jati, Kudus (Rosyid, 2019).

\section{Strategi Mengenalkan Cinta al-Quran di Lembaga Hidayatullah Kudus}

Semangat pendidik dalam pembelajaran untuk mendalami Islam (islamic learning), bukan mempelajari tentang Islam (learning about Islam) sebagai faktor pembeda dengan lembaga lain. Maksud mendalami Islam yakni belajar tentang Islam dengan mendalam, tidak hanya aspek teori keislaman saja. Selain itu, direalisasikan syariat Islam dalam kehidupan santri di asrama dengan pantauan guru pamong. Keberadaan guru pamong mengevalusi sikap disiplin, jujur, dan berakhlakul karimah agar menjadi sisiwa yang unggul, berprestasi, dan cinta al-Quran. Langkah nyatanya mewujudkan karakter siswa dengan materi pembelajaran praktek ibadah salat wajib lima waktu berjamaah (bagi yang di asrama), mengkaji al-hadis, praktek berbahasa Arab, halaqoh (pendampingan wali kelas pada anak didik dalam hal tilawah al-Quran), tadarus al-Quran mengkaji adab membaca alQuran setiap hari. Bahkan diberi materi pelajaran al-Quran dua jam pelajaran (belajar membaca dan menulis al-Quran) dan mapel tahfid (menghapal al-Quran). Hal ini dijadikan dasar mengenalkan al-Quran sejak di kelas 1 SDIT Luqman al Hakim Hidayatullah di Kudus.

Pembelajaran mulai pukul 07.15 hingga $13.10 \mathrm{Wib}$ (meski kelas 1 SD di SD lainnya pulangnya pukul $10.00 \mathrm{Wib}$ ) sedangkan pada Hari Jumat pulang pukul 11.00 Wib. Pelaksanaan pembelajaran menggunakan kurikulum integral yakni mengintegrasikan nilai keislaman (tauhid) juga menggunakan kurikulum nasional yakni mata pelajaran tematik, bahasa Jawa, dan pendidikan jasmani dan olahraga kesehatan. Tujuan mengintegrasikan 
kurikulum agar anak didik teguh berakidah Islam, beribadah dengan baik dan benar. Nilai spiritual ditumbuhkan dengan pribadi yang jujur, disiplin, taat beribadah agar terbentuk calon pemimpin Islam yang amanah. Peran guru sebagai tauladan dijadikan pionir bagi siswa menauladani sebagai bekal pembentuk karakter.

Jadwal Pelajaran SDIT Luqman al Hakim Kudus Kelas 1 Tahun Pelajaran 2019/2020

\begin{tabular}{|c|c|c|c|c|c|c|}
\hline Waktu & Senin & Selasa & Rabu & Kamis & Jumat & Sabtu \\
\hline $07.15-.50$ & $\begin{array}{l}\text { Apel } \\
\text { Motivasi }\end{array}$ & Tahfid & Tahfid & Tahfid & Tahfid & Tahfid \\
\hline $\begin{array}{l}07.50- \\
08.25\end{array}$ & Al-Quran & Tematik & Al-Quran & PJOK & Tematik & Halaqoh \\
\hline $\begin{array}{l}08.25- \\
09.00\end{array}$ & Al-Quran & Tematik & Al-Quran & PJOK & Tematik & Al-Quran \\
\hline $\begin{array}{l}09.00- \\
09.35\end{array}$ & Tematik & Al-Quran & Tematik & $\begin{array}{l}\text { Al- } \\
\text { Quran }\end{array}$ & Transisi & Al-Quran \\
\hline $\begin{array}{l}09.35- \\
10.10\end{array}$ & Tematik & Al-Quran & Tematik & $\begin{array}{l}\text { Al- } \\
\text { Quran }\end{array}$ & PAI & Transisi \\
\hline $\begin{array}{l}10.10- \\
10.25\end{array}$ & Transisi & Transisi & Transisi & Transisi & PAI & Tematik \\
\hline $\begin{array}{l}10.25- \\
11.00\end{array}$ & Bahasa Arab & $\begin{array}{l}\text { Bahasa } \\
\text { Jawa }\end{array}$ & Tematik & Tematik & Pulang & Tematik \\
\hline $\begin{array}{l}11.00- \\
11.35\end{array}$ & Bahasa Arab & Literasi & Tematik & Tematik & & Pulang \\
\hline $\begin{array}{l}11.35- \\
12.35\end{array}$ & Ishoma & Ishoma & Ishoma & Ishoma & & \\
\hline $\begin{array}{l}12.35- \\
13.10\end{array}$ & Tematik & Hadis & $\begin{array}{l}\text { Praktek } \\
\text { ibadah }\end{array}$ & Tematik & & \\
\hline
\end{tabular}

(Moh Rosyid, 2021:238).

Program unggulannya siswa ditradisikan salat wajib dan sunah, membaca al-Quran setiap hari, dan menghapalkannya minimal 3 juz sebagai syarat tamat SD. Hal ini membentuk karakter anak tertanam pada dirinya mencintai al-Quran.

\section{Pendidikan Karakter Lembaga Hidayatullah di Kudus}

Model pembelajaran lembaga ini meliputi inquiri, project, problem based learning, dan discovery learning yang dipadu dalam tiga gaya belajar yakni visual (melihat), auditory (mendengar), dan kinetic (gerak). Qiroah (membaca al-Quran dengan merdu), tilawah (membaca al-Quran dengan fasih), kaligrafi (seni menulis huruf Arab) merupakan kombinasi visual dan auditory, sedangkan kepramukaan, memanah/panahan, pianika, paduan suara, rebana, beladiri, jurnalistik, dan seni mewarnai merupakan gaya belajar kinetik yang tertuang dalam ekstrakulikuler. Aktifitas ekstrakulikuler peminat terbanyak yakni tilawah dan memanah. Hal ini sebagai penanda bahwa membaca al-Quran dengan fasih menjadi pilihan perioritas, disusul memanah yang didoktrin guru bahwa memanah 
merupakan keterampilan yang tertradisi dalam Islam, utamanya masa perang di zaman Nabi SAW. Adapun ekstrakulikuler yang paling minim peminatnya adalah paduan suara karena siswa menganggap kegiatan yang kemanfaatannya masih besar tilawah dan memahan. Profil yang diharapkan lurus akidahnya, berakhlak al-Quran, beribadah dengan berjamaah sebagai komitmennya untuk bekal mewujudkan kecerdasan qolbu. Kredonya, membuka hati dengan pendidikan integral berbasis tauhid.

Kemampuan mewujudkan konsep pendidikan karakter/nilai sebagai faktor pembentuk kepribadian peserta didik. Pendidikan karakter menurut Koesoema, bila pendidikan memadukan semua aspek pendidikan di dalam dan di luar sekolah. Bentukan karakternya berupa tanggung jawab, berdaya juang, cintai kebenaran, pemberani, dan menghargai perbedaan (Koesoema, 2016). Menurut Zuchdi, keberhasilan pendidikan karakter apabila semua pihak yang terlibat dalam pembelajaran melaksanakan aturan sesuai usia anak didik dengan tauladan dari pendidik, sejak di kelas yang kemudian dipraktekkan dalam kehidupan (Zuchdi, 2008:36). Aplikasi sosialnya bila anak hidup bersama masyarakatnya. Pedidikan karakter menjadi kebutuhan, sebagaimana Sekolah Dasar Islam Terpadu (SDIT) Luqman al Hakim Hidayatullah di Kudus mempunyai kekhasan dengan ciri mampu membaca dan menghapal al-Quran sejak usia sekolah dasar.

Pada jangka panjang, pendidikan karakter bertujuan mengenalkan nilai secara kognitif, penghayatan secara efektif dan mengamalkan nilai tersebut dalam kehidupan. Prinsip dasarnya terwujudnya fungsi dan tujuan pendidikan yakni kemampuan dan pembentuk watak yang bermartabat untuk kecerdasan anak bangsa, berkembangnya potensi iman dan takwa, berakhlak mulia, sehat, berilmu, cakap, kreatif, mandiri, demokratis, dan bertanggung jawab (Pasal 3 UU Nomor 20 Tahun 2003 tentang Sisdiknas). Hal ini merupakan tujuan pendidikan nasional secara luas, secara praktis yakni pembentuk diri menjadi baik dan cerdas (good and smart) dalam perilaku dan berpikir cerdas. Jadi, keberhasilan pendidikan karakter adalah kemampuan mengader anak didik menjadi baik perilakunya dan kualitas pemikirannya. Wujud keberhasilannya bila menyatu antara suasana keluarganya, lembaga pendidikannya, dan masyarakatnya. Pendidikan karakter merupakan seluruh aspek pendidikan atau pembimbingan pada siswa supaya sadar atas nilai yang benar, baik, dan indah dengan proses yang tepat dan konsisten dalam membiasakan dalam bertindak.

Tujuan pendidikan karakter pembentuk pribadi yang utuh, berkarakter dalam seluruh praktik pendidikan di sekolah berbentuk kurikulum, ekstrakurikuler, dan upaya lainnya. Hal ini mencakup nilai (value) agama, nilai budaya, nilai etika, dan nilai estetika menuju terbentuknya pribadi cerdas keagamaan, pengendali diri, berkepribadian utuh, berakhlak mulia, dan terampil. Adapun misi pendidikan karakter/nilai (1) membina peserta didik agar memahami dan menyadari karakter nilai diri dan orang lain, (2) berakhlakul karimah dan melakukan pembelajaran yang berproses pembinaan karakter/nilai dengan pendekatan menyeluruh, membantu anak didik agar paham, sadar, dan memahami nilai dan 
mumpuni menempatkan secara padu dalam hidupnya (Sauri dan Hufad, 2007:41). Fungsi pendidikan karakter berupa (1) seleksi terhadap nilai yang terdapat dalam filsafat yang menempatkan ahli pendidikan karakter untuk menata kerangka berpikir filosofis agar terartikulasikannya nilai unggul, (2) menyeleksi atas nilai dalam ilmu pengetahuan yang menempatkan ahli pendidikan karakter/nilai agar selalu mencermati dan mengkaji perkembangan ilmu pengetahuan yang berimplikasi pada ilmu pengetahuan, dan (3) menyeleksi atas nilai dalam teori pendidikan yang menempatkan ahli dan praktisi pendidikan nilai untuk mencermati dan memilih teori pendidikan yang sesuai kebutuhan agar menjadi diri berjati diri.

Pendidikan karakter lahir karena pendidikan masih memfokuskan pada kecerdasan akademik dengan ukuran nilai (angka) dan kelulusan yang bersifat numerik. Tingginya angka tidak menjamin anak didik mampu menjadi ilmuwan yang memegang etika dan sukses dalam bersosialisasi. Unsur karakter dalam pendidikan karakter meliputi religiositas, jujur, toleran, disiplin, cinta kedamaian, bertanggung jawab, peduli sesama dan ramah lingkungan, kreatif, gemar membaca, pembiasaan dan ketauladanan melalui budaya sekolah, pembiasaan di rumah, dan kegiatan kurikuler, kokulikuler, dan ekstrakulikuler. Ekstrakulikuler meliputi berupa kepanduan, karya tulis, olahraga, pendalaman praktek beragama seperti pemahaman toleransi beragama dan bersuku, ras, mencintai lingkungan fisik dan nonfisik, dsb. Unsur-unsur itu termaktub pada ranah afektif (pemikiran/pembelajaran) dan psikomotorik (praktik kehidupan) disertai evaluasi melekat dan berkesinambungan. Analisa Bagir, janganlah niat baik pengembangan pendidikan karakter dan moral dirancang untuk mendorong semangat kesalehan anak didik yang salah penempatan (misplaced pietism), salah penggunaan (misused) yang melahirkan perilaku yang bertentangan dengan tujuan pendidikan karakter (Baqir, 2013:6). Menurut Pawitasari ada enam prinsip pendidikan karakter islami (1) menjadikan Tuhan sebagai tujuan, (2) memperhatikan akal/rasio, (3) memperhatikan perkembangan kecerdasan emosi, (4) praktik melalui keteladanan dan pembiasaan, (5) memperhatikan pemenuhan kebutuhan hidup, dan (6) memprioritaskan nilai (Pawitasari, 2013:23).

Ada tiga matra pendidikan karakter, yakni individu, sosial, dan moral yang merupakan kesatuan matra dalam memberi perhatian pada perkembangan anak dengan mengukuhkan diri sebagai makhluk bermoral, membuat pendidikan karakter memiliki fungsi pedagogis. Visi pendidikan karakter adalah cita-cita menuju kinerja lembaga pendidikan. Bila peserta didik dilibatkan maka jiwa pendidikan karakter merupakan bagian keyakinan diri anak didik dan komunitas lembaga pendidikan (Koesoema, 2007:145 dan 156). Adapun dimensi pendidikan karakter adalah pendidikan nilai dan pendidikan moral. Nilai adalah suatu kualitas yang menjadikan suatu itu disukai, diinginkan, dan dihargai dan menjadi obyek bagi kepentingan tertentu. Pendidikan moral menjadi dasar pendidikan karakter. Pendidikan moral sebagai usaha individu untuk membentuk dan mengafirmasi diri dan menjadi pribadi bermoral. Moral merupakan pemahaman atas nilai dan norma 
yang menjadi pegangan bagi individu dalam komunitas agar kebebasan dan keunikan tiap diri tak dilanggar sehingga menghargai martabat masing-masing.

Ada pembeda antara pendidikan karakter dengan pendidikan moral, pendidikan moral ruang lingkupnya kondisi batin individu untuk sadar diri. Adapun pendidikan karakter bertujuan menegakkan martabat manusia sebagai individu (Koesoema, 2007:195). Dimensi sosial pendidikan karakter, terciptanya sistem sosial yang kondusif bagi pertumbuhan pribadi. Adapun basis pendidikan karakter yakni kelas, kultur sekolah, dan komunitas. Aspek yang perlu dievaluasi dalam pendidikan karakter (1) menemukan momen pembentuk karakter pada saat pembelajaran, (2) ekstrakuler dapatkah mengembangkan keterampilan, minat, bakat dan kemampuan di bidang olahraga, seni, budaya, kelompok diskusi, jurnalistik, dan peminatan bakat lainnya, dan (3) sejauhmana kolaborasi antara sekolah dan rumah, lembaga pendidikan dan masyarakat sekitar lembaga pendidikan (Koesoema, 2016:6). Hal tersebut perlu diperkokoh dengan evaluasi yang berkesinambungan oleh lembaga, pendidikan, dan tenaga kependidikan. Dengan demikian, obsesi terwujudnya generasi yang fasih membaca al-Quran dan calon da'i yang karakter hidupnya sebagaimana yang diajarkan dalam al-Quran sejak usia dini terwujud didukung oleh lingkungan pendidikan yang disiplin dan tauladan guru yang ideal.

\section{KESIMPULAN}

Lembaga Pendidikan Hidayatullah di Kudus di bawah naungan Yayasan al-Aqsha Kudus. Kekhasan strategi pembelajarannya agar peserta didik cinta al-Quran sejak usia dini menjadi kekhasan di SDIT Luqmanul Hakim di Kudus. Anak didik identik dengan membawa dan membaca al-Quran di asrama, kelas, dan masjid, meski masih usia dini(sejak kelas 1 SD). Salat wajib dan sunah berjamaah menjadi rutinitasnya sehingga mudah ditradisikan pada usia dewasa. Unsur karakter dalam pendidikan karakter meliputi religiositas, kejujuran, disiplin, cinta damai, tanggung jawab, kreatif, suka membaca alQuran dan menghapalnya dijadikan kebiasaan dan menjadi budaya sekolah. Peran pendidik sangat besar sebagai guru pamong di asrama. Karakter gemar membaca dan menghapal alQuran karena usia anak-anak memerlukan pembiasaan, adanya fasilitas pendukung utama, dan guru sebagai pionir bagi peserta didik sebagai faktor keberhasilan mewujudkan pendidikan karakter. Hal ini merujuk pada Piagam Hidayatullah yang menjadi keharusan menaati bagi warga Hidayatullah.

Model pembelajarannya inquiri, project, and problem based learning, dan discovery learning dipadu dalam tiga gaya belajar yakni visual (melihat), auditory (mendengar), dan kinetic (gerak). Qiroah (membaca al-Quran dengan merdu), tilawah (membaca al-Quran dengan fasih), kaligrafi (seni menulis huruf Arab), pramuka, panahan, pianika, paduan suara, rebana, beladiri, jurnalistik, dan seni mewarnai merupakan ragam ekstrakulikulernya. Keberlangsungan lembaga pendidikan Hidayatullah di Kudus perlu membuat terobosan agar kualitas alumninya semakin unggul. Pertama, fasilitas 
pembelajaran meliputi media, sumber, dan sarana selalu dioptimalkan dengan pendekatan multimedia yang canggih. Kedua, perekrutan guru mengutamakan profesionalisme agar tidak terkesan eksklusif. Ketiga, membuka peluang kerja sama dengan ragam lembaga agar kesan (dikesankan) eksklusif makin memudar dengan adanya semboyan "daripada mengkaji ilmu fikih yang dianggapnya sumber polemik intern-umat Islam" dan bila tidak mewaspadai akan meruncing menjadi konflik karena kurang dewasanya menyikapi perbedaan pandangan dalam fikih.

\section{DAFTAR PUSTAKA}

Bagir, Haidar. 2013. Problem Pendidikan Karakter. Kompas, 9 Januari 2013.

Dianto, Ageng Mei. 2014. Peranan Lembaga Amil Zakat Nasional Baitul Maal Hidayatullah dalam Meningkatkan Kesejahteraan Mustahiq Kabupaten Tulungagung. Jurnal an-Nisbah, Vol.01, No.01, Oktober.

Koesoema, A.Doni. 2007. Pendidikan Karakter Strategi Mendidik Anak di Zaman Global. Grasindo: Jakarta.

Rosyid, Moh. 2019. Lembaga Pendidikan dan Kaderisasi Da'i: Studi Kasus pada Lembaga Pendidikan Hidayatullah di Kudus. Jurnal Tasamuh UIN Mataram, Vol.17. No.1.

-----. 2021. Pendidikan Integral Berbasis Tauhid di Lembaga Pendidikan Hidayatullah Kudus Jawa Tengah. Jurnal Perspektif Balai Diklat Agama Palembang. Vol.14, No.2, Juli 2021.

Rukah. 2019. Peran Amil Zakat Baitul Maal Hidayatullah dalam Pendayagunaan Zakat Melalui Program Senyum Anak Indonesia Studi Kasus di Ponpes al-Burhan Hidayatullah Gedawang, Banyumanik, Kota Semarang. Skripsi Jurusan Manajemen Dakwah Fakultas Dakwah dan Komunikasi UIN Walisongo Semarang.

Salbu, Manshur. 2009. Mencetak Kader: Perjalanan Hidup Ustad Abdullah Said Pendiri Hidayatullah. Surabaya: Suara Hidayatullah Publishing.

Sauri, Sofyan dan Achmad Hufad. 2007. Pendidikan Nilai dalam Ilmu dan Aplikasi Pendidikan. Bagian 3. UPI: Bandung.

Tim Peneliti IAIN Antasari. 2003. Ponpes Hidayatullah Balikpapan. Puslit IAIN Antasari, Banjarmasin.

Zein, Nashrur Rahman. 2018. Ponpes Hidayatullah Yogyakarta di Balong, Donoharjo, Ngaglik, Sleman (1989-2016 M). Skripsi Jurusan Sejarah dan Kebudayaan Islam Fakultas Adab dan Ilmu Budaya UIN Sunan Kalijaga Yogyakarta.

Zuchdi, Darmiyati. 2008. Humanisasi Pendidikan. Bumi Aksara: Jakarta. 2008. 